\title{
METODE LATIHAN BERMAIN UNTUK MENINGKATKAN POWER OTOT TUNGKAI ATLET BOLAVOLI PADA TIM PERVIK KEDIRI TAHUN 2018
}

\author{
Slamet Junaidi \\ Program Studi Pendidikan Jasmani, Kesehatan dan Rekreasi, Universitas PGRI Kediri, Kediri, Indonesia \\ *slamet.junaidi@unpkediri.ac.id
}

(Received: February 2019 / Revised: March 2019 / Accepted: March 2019)

\begin{abstract}
ABSTRAK: Tujuan penelitian ini adalah untuk mengetahui pengaruh metode latihan bermain terhadap power otot tungkai atlet bolavoli. Penelitian ini merupakan penelitian eksperimen. Subyek penelitian ini adalah seluruh atlet putri pervik kelahiran tahun 2003 yang akan ikut seleksi menjadi tim liga remaja Kota Kediri sebanyak 12 pemain, untuk disiapkan pada Liga remaja Juli 2018 di Ngawi. Teknik sampling yang digunakan adalah penelitian populasi. Instrumen dalam penelitian ini menggunakan tes dan pengukuran. Untuk mengetahui power otot tungkai menggunakan vertical jump. Analisis data menggunakan uji t dengan taraf signifikansi 5\%. Berdasarkan hasil analisis data dengan menggunakan uji t diketahui nilai Sig. $<0,05$ maka $\mathrm{H}_{0}$ ditolak, berarti dapat disimpulkan ada pengaruh metode latihan metode bermain terhadap power otot tungkai atlet bolavoli.
\end{abstract}

KATA KUNCI: Latihan, Bermain, Metode, Power, Bolavoli.

ABSTRACTS: The purpose of this study was to determine the effect of playing training methods on the power of limb muscles of volleyball athletes. This research is an experimental research. The subjects of this study were all female athletes born in 2003 who will take part in the selection to become a youth league team in Kota Kediri with 12 players, to be prepared in the July 2018 youth League in Ngawi. The sampling technique used is population research. The instruments in this study used tests and measurements. To find out leg muscle power using vertical jump. Data analysis using t test with a significance level of $5 \%$. Based on the results of data analysis using the $t$ test it is known the Sig. $<0.05$, then $\mathrm{HO}$ is rejected, meaning that it can be concluded that there is an effect of the method of playing method on the power of limb muscles of volleyball athletes.

KEYWORD: $\quad$ Exercise, Play, Method, Power, Volleyball.

\section{PENDAHULUAN}

Olahraga adalah suatu aktivitas yang banyak dilakukan oleh masyarakat, keberadaannya sekarang ini tidak lagi dipandang sebelah mata tetapi sudah menjadi bagian dari kehidupan masyarakat. Olahraga dewasa ini sudah menjadi gaya hidup di masyarakat baik orang tua, remaja maupun anak-anak. Olahraga mempunyai makna tidak hanya untuk kesehatan, tetapi juga sebagai sarana pendidikan bahkan prestasi (Prakoso \& Sugiyanto, 2017). Menurut Maksum (2011) mendefinisikan olahraga sebagai aktivitas fisik berupa permainan yang berisikan perjuangan melawan unsur-unsur alam, orang lain, diri sendiri, dan memiliki kompleksitas organisasi.
Latihan yang memiliki berbagai macam metode selalu menunjukkan perkembangan konsep yang benar dalam melakukan gerakan dan pelaksanaanya (Pratiwi, Setijono, \& Fuad, 2018).

Permainan bolavoli merupakan permainan yang populer saat ini. Kepopulerannya nampak pada antusiasme penonton dalam setap kejuaraan, mulai dari kejuaraan antar sekolah, POPDA, POPNAS, O2SN hingga Proliga. Permainan bolavoli adalah permainan beregu yang dimainkan oleh dua tim dan setiap tim terdiri dari enam pemain. Permainan bolavoli merupakan suatu permainan yang komplek yang tidak mudah dilakukan oleh setiap orang (Muttaqin, Winarno, \& Kurniawan, 2016). 
Journal of Sport and Exercise Science, Vol 2, No 1, 2019 (21-28)

Metode Latihan Bermain Untuk Meningkatkan Power Otot Tungkai Atlet Bolavoli

Pada Tim Pervik Kediri Tahun 2018

Teknik dasar bermain bolavoli merupakan unsur yang sangat penting dalam permainan bolavoli, tanpa penguasaan teknik dasar yang baik, maka permainan tidak dapat dimainkan dengan sempurna. Teknik dasar bolavoli memiliki peranan yang sangat penting sebelum para pemain meningkatkan kemampuan pada keterampilan yang lebih tinggi (Yudasmara, 2014).

Dalam suatu cabang olahraga, dia harus mempunyai kemampuan penguasaan teknik, taktik sesuai dengan cabang olahraga yang diminati nya, mempunyai mental yang baik, sarana dan prasarana yang diperlukan dalam latihan dan permainan, dan disamping itu yang tak kalah penting memiliki kondisi fisik yang baik. Faktor-faktor diatas tersebut merupakan satu kesatuan yang saling terkait satu dengan yang lainnya dan tidak dapat dipisahkan. Tanpa kondisi fisik yang baik tidak mungkin seseorang mampu merealisasikan teknik dengan baik serta tanpa taktik dan mental yang baik, juga tidak akan dapat melahirkan prestasi yang maksimal (Purnama, 2015). Physical condition is a necessary requirement in improving an athlete's performance, and may even be regarded as a basic necessity that cannot be postponed or negotiable (Hanief, Puspodari, \& Sugito, 2017)

Kondisi fisik terbagi menjadi dua, yaitu kondisi fisik umum dan kondisi fisik khusus (Maliki, Hadi, \& Royana, 2017). Kondisi fisik umum merupakan kemampuan dasar dalam mengembangkan kemampuan prestasi tubuh yang dimiliki. Kemampuan dasar itu meliputi kekuatan umum, kecepatan umum, daya tahan umum dan kelentukan umum. Kondisi fisik khusus merupakan kemampuan fisik yang dikhususkan untuk suatu cabang olahraga tertentu (Maliki et al., 2017). Komponen fisik yang perlu diperhatikan untuk dikembangkan ada beberapa, diataranya adalah daya tahan kardiovaskuler, daya tahan kekuatan, kekuatan otot (strength), kelentukan (flexibility), kecepatan, stamina, kelincahan (agility), daya ledak otot (power), daya tahan kekuatan (strength endurance).

Daya ledak otot tungkai (power) merupakan salah satu komponen kondisi fisik yang dominan pada permainan bolavoli. Daya ledak otot (power) yaitu gabungan antara kekuatan dan kecepatan atau pengerahan gaya otot maksimum dengan kecepatan maksimum (Rizaldianto, 2016). Daya ledak otot tungkai digunakan pemain untuk melompat da melakukan smash. Penguasaan teknik dasar smash dalam permainan bolavoli sangat penting, keberhasilan suatu regu dalam memenangkan bolavoli banyak ditentukan oleh smash, sebab smash merupakan cara termudah untuk memenangkan angka, oleh karena itu setiap pemain dalam satu tim harus benar-benar menguasai smash dengan baik, karena smash merupakan serangan utama (Muchlisa, 2017).

Tim Pervik kota Kediri sebagai salah satu klub bolavoli dikota Kediri, akan ikut seleksi pada pembentukan tim bolavoli Liga Remaja kota Kediri, yang akan bertanding di Ngawi Juli 2018, perlu menyiapkan atletnya baik fisik maupun tekniknya. Dalam membentuk tim bolavoli ini, diawali dengan proses pemilihan atlet secara terbuka bagi atlet di klub bolavoli yang ada di klub Pervik secara terbuka, yang memenuhi persaratan umur kelahiran 2013 dan sudah memiliki kemampuan untuk bertanding. Berdasar pengamatan pelatih, data saat seleksi pemain calon tim bolavoli putri tahun 2018, dan data tes pengukuran bulan Desember 2017, maka power atau daya ledak otot tungkai 12 atlet bolavoli perlu ditingkatkan, guna mendukung penampilannya menerapkan teknik bermain bolavoli, seperti saat melakukan smash, block dan jump serve. Rata-rata tinggi lompatan atlet bolavoli putri $41,5 \mathrm{~cm}$ yang dipersiapkan sebagai wakil tim Pervik Kediri pada seleksi bulan Juni 2018 di GOR Universitas Nusantara PGRI Kediri.

Penulis berupaya meningkatkan lompatan para atlet yang dihasilkan oleh daya ledak otot tungkai dengan sebuah metode, yakni metode 
latihan bermain. Latihan merupakan salah satu langkah yang efektif dalam membantu meningkatkan prestasi suatu cabang olahraga, dengan tujuan meningkatkan fisik, teknik, taktikstrategi maupun mental. Fisik merupakan salah satu unsur yang perlu dilatih dalam proses latihan dengan tujuan meningkatkan dan mempertahankan unsur biomotor atau kondisi fisik atlet. Menurut Nurhasan (2008), komponen fisik yang perlu dikembangkan seseorang yang berolahraga untuk meningkatkan prestasinya, meliputi kekuatan, daya ledak, kecepatan, kelentukan, kelincahan,keseimbangan, kecepatan reaksi dan daya tahan.

Metode atau pola latihan dengan situasi pertandingan mulai banyak dikembangkan dalam meningkatkan kemampuan bermain, dimana pola ini pelaksanaan pembelajaran atau pelatihan dengan invasion games adalah pendekatan situasi pertandingan. Disamping itu, kerangka kerja tersebut merupakan pedoman untuk mengembangkan masalah taktik yang akan dikembangkan (Yudanto,2013). Agustiyanto (2011) memberi pengertian tentang games situation merupakan metode latihan olahraga seperti dimana situasi latihan seperti bertanding.

Dasar berlatih teknis dalam bentuk permainan ini, banyak dikembangkan di Jerman Barat, dalam permainan dua lawan dua, tiga lawan tiga , dengan lebar lapangan yang awalnya dipersempit (Dieter B, 2013). Dengan hanya dua atau tiga pemain di dalam lapangan, pemain belajar menguasai segala teknik bermain bolavoli secara utuh sekaligus melatih fisik menguasai lapangan yang lebih luas.

Pola latihan atau belajar bermain bolavoli dengan memodifikasi latihan, dengan mengurangi jumlah pemain atau aturan permainannya yang di modifikasi ini, sangat diperlukan, sebelum atlet tumbuh menjadi besar dalam mendukung permainannya (Agus, 2010). Jadi latihan meningkatkan teknik bermain bolavoli tidak harus enam lawan enam, tapi bisa menyesuaikan dengan kondisi fisik anak, bisa empat lawan empat, lima lawan lima.

Karena permainan bolavoli merupakan jenis olahraga pertandingan, dimana ada lawan, maka dalam proses latihan juga perlu diadaptasikan pola latihan dengan ada lawan, ada yang menyerang ada yang bertahan, dimana bentuk latihan bisa disesuaikan dengan verakan bermain bolavoli (Dieder, 2013). Bentuk latihan meningkatkan fisik yang lain bisa dengan variasi, melempar, menangkap, bergerak menerima bola yang dilakukan sambil berlari dan melompat (Barbara dkk, 2014).

Dari dasar tersebut, maka metode latihan yang diterapka pada atlet Pervik Kediri yang dipersiapka dalam menghadapi liga remaja 2018, dengan bentuk latihan bermain dengan melempar, melempar, menangkap bola sambil melompat, dengan tujuan untuk meningkatkan kemampuan power otot tungkainya.

Hasil studi literatur, belum ditemukan penelitian terdahulu tentang metode bermain untuk meningkatkan daya ledak otot tungkai. Hasil temuan ini nantinya diharapkan dapat memperkaya ilmu pengetahuan dibidang olahraga, khususnya peningkatan daya ledak otot tungkai melalui metode bermain. Namun, beberapa penelitian menyimpulkan bahwa metode bermain dapat meningkatkan berbagai macam keterampilan dan skil. Penelitian Wijaya (2013) menyimpulkan bahwa metode bermain dapat meningkatkan kemampuan passing bawah bolavoli peserta ekstrakurikuler SMA N 1 Bantul.

\section{METODE PENELITIAN}

Metode penelitian ini memakai metode eksprimen dengan pendekatan kuantitatif, dengan pretes post tes design. Pretest dilakukan Minggu kedua bulan Maret tahun 2018 untuk mengetahui kemampuan awal daya ledak otot tungkai para atlet. Latihan dilakukan tiga kali seminggu tiap hari 
Journal of Sport and Exercise Science, Vol 2, No 1, 2019 (21-28)

Metode Latihan Bermain Untuk Meningkatkan Power Otot Tungkai Atlet Bolavoli

Pada Tim Pervik Kediri Tahun 2018

Selasa, Kamis dan Sabtu, selama lima minggu. Program latihan dilakukan di awal latihan setelah atlet melakukan pemanasan. Setelah menjalani proses latihan dengan metode bermain ini, atlet baru melakukan latihan tehnik dengan menggunakan bola. Posttest dilakukan pada minggu ketiga bulan April tahun 2018, dimana pengambilan data pretest dan posttest dilakukan dengan tes dan pengukuran vertical jump, sebanyak dua kali, diambil terbaik. Yang menjadi subyek penelitian ini adalah seluruh atlet putri Pervik kelahiran tahun 2003 yang akan ikut seleksi menjadi tim Liga Remaja Kota Kediri sebanyak 12 pemain, untuk disiapkan pada Liga Remaja Juli 2018 di Ngawi.

Sebelum latihan, setiap atlet diberi pemanasan secara beregu, dari penguluran, lari kecil, senam ataupun dalam bentuk permainan sederhana dengan tujuan menaikkan suhu tubuh dan menyiapkan kondisi fisik dan mental sebelum ke latihan yang sebenarnya. Bentuk latihan sebagai berikut:

\begin{tabular}{|l|l|l|l|}
\hline oo & & & \\
00 & & & 00 \\
& & & \\
\hline
\end{tabular}

Gambar 1. Bentuk Latihan.
a. Lari, melompat tepuk tangan di atas net tim A dengan tim $B$.

Pemain A berlari dan pemain B(tidak membawa), lalu melompat bersama di depan net, tepuk tangan di atas net di tengah lapangan, lalu yang kanan bergeser ke kenan, yang kiri putaran ke kiri, melompat dan tepuk tangan lagi di atas net. Dilakukan $8 \times$ putaran atau 16 lompatan. Putaran kedua, dimulai dari tepi lapangan, lalu bergeser ketengah lapangan, 2 pemain tim A dan
2 pemain tim B, melompat bersamaan, dilakukan $8 \mathrm{X}$ putaran atau $16 \mathrm{X}$ lompatan.

b. Tukar bola di atas net tim A bawa bola, oleh tim B.

Pemain A berlari membawa bola ke depan net bersamaan pemain $B$ (tidak membawa), lalu melompat bersama di depan net, tukar bola di atas net $2 \mathrm{x}$ di tengah lapangan, bola kembali di A dan melempar ke teman di belakangnya dan seterusnya. Dilakukan 8 purtaran atau 16 lompatan

c. Tukar bola di atas net tim A, dengan oleh tim $B$, ditengah dan pinggir lapangan.

Pemain A berlari membawa bola ke depan net bersamaan pemain $B$ (tidak membawa), lalu melompat bersama di depan net, tukar bola di atas net $2 \mathrm{x}$ di tengah dan $2 \mathrm{x}$, bola kembali di $\mathrm{A}$ dan melempar ke teman di belakangnya dan seterusnya. Dilakukan $8 \times$ putaran atau 32 lompatan.

\section{d. Lempar terima bola.}

Pemain A membawa bola, lari ke depan net, melompat dan melempar bola kearah B terdepan, A lalu mundur, pemain B menerima dan dan melakukan seperti A. dilakukan 8 kali putaran, dilanjutkan pemain bergeser ke tepi lapangan, dilakukan $8 \times$ lemparan, tiap anak melompat $16 \mathrm{X}$ lompatan.

e. Lari, lompat, pantul.

Atlet A bawa bola, lari ke depan net, melompat tinggi dan memantulkan bola ke seberang lawan, pemain B menangkap dan ganti berlari, lompat dan memantulkan bola diatas net. Latihan ini dilakukan ditengah lapangan sebanyak $8 \mathrm{X}$, dan tepi $8 \mathrm{X}$, sehingga masing-masing melompat $16 \mathrm{X}$. Tinggi net terkadang diturunkan $10 \mathrm{~cm}$ agar lebih mudah dan lancar saat memantulkan bola sambil melompat di atas net. 
f. Bermain pass atas di tengah lapangan sambil melompat.

Pemain belajar dan berlatih tiga sentuhan dengan belajar dan berlatih teknik pass bawah, pemain mengumpan, smash, dengan bola makin lama makin keras, dimana hanya pemain yang di depan yang berhak menyentuh bola 3 sentuhan, berhasil, geser belakang bisa dilanjutkan bermain 2 vs 2 atau 3 vs 3 atau 3 vs 4 pemain yang selalu disesuaikan. Jadi terbiasa menguasai teknik teknik bermain.

\section{HASIL}

Hasil yang diperoleh dari penelitian berupa data yang merupakan gambaran umum tentang masing-masing variabel yang terkait dalam penelitian. Melalui gambaran umum ini akan nampak kondisi awal dan kondisi akhir dari setiap variabel yang diteliti dengan melakukan pengolahan data setelah data berhasil dikumpulkan selama periode latihan yang telah ditentukan. Berikut akan dijelaskan pada Tabel 1:

Tabel 1. Deskripsi Data Hasil Pretest dan Posttest Daya Ledak Otot Tungkai.

Std.

$\mathrm{N}$ Minimum Maximum Mean Deviation

\begin{tabular}{llllll}
\hline Pretest & 12 & 40 & 49 & 45.33 & 2.871 \\
\hline Posttest & 12 & 42 & 52 & 48.00 & 3.275 \\
\hline Valid N & 12 & & & & \\
(listwise) & 12 & & & & \\
\hline
\end{tabular}

Berdasarkan tabel 1 dapat diketahui nilai minimum pada saat pretest sebesar 40, maksimum sebesar 49 , nilai rata-rata (mean) sebesar 45,33 dan nilai standar deviasi sebesar 2,871 . Pada saat posttest diperoleh nilai minimum sebesar 42 , maksimum sebesar 52 , nilai rata-rata (mean) sebesar 48 dan nilai standar deviasi sebesar 3,275.

Hasil analisis data meliputi hasil uji normalitas, uji homogenitas dan uji t (uji beda). Masing-masing hasil disajikan pada tabel berikut:
Tabel 2. Hasil Uji Normalitas Data.

\begin{tabular}{lrrrrrr}
\hline & \multicolumn{3}{c}{$\begin{array}{c}\text { Kolmogorov- } \\
\text { Smirnov }^{a}\end{array}$} & \multicolumn{3}{c}{ Shapiro-Wilk } \\
\cline { 2 - 7 } & Statistic & df & Sig. & Statistic & df & Sig. \\
\hline $\begin{array}{l}\text { Vertical } \\
\text { Jump }\end{array}$ & .157 & 12 & $.200^{*}$ & .930 & 12 & .375 \\
\hline
\end{tabular}

Berdasarkan hasil uji normalitas pada tabel 1 dapat diketahui bahwa nilai Sig. untuk hasil Kolmogorov-Smirnov sebesar 0,200 dan ShapiroWilk sebesar 0,375 $>0,05$ sehingga dinyatakan data berdistribusi normal.

Tabel 3. Hasil Uji Homogenitas.

\begin{tabular}{crrrr}
\hline $\begin{array}{l}\text { Levene } \\
\text { Statistic }\end{array}$ & df1 & & df2 & \multicolumn{1}{c}{ Sig. } \\
\hline .253 & & 1 & 22 & .620 \\
\hline
\end{tabular}

Berdasarkan hasil uji homogenitas pada tabel 2 dapat diketahui bahwa nilai Sig. untuk hasil Kolmogorov-Smirnov sebesar 0,200 dan ShapiroWilk sebesar 0,375 $>0,05$ sehingga dinyatakan data berdistribusi normal.

Untuk mengetahui ada tidaknya perbedaan antara sebelum dan sesudah perlakuan maka dilakukan uji beda yang ditunjukkan pada tabel berikut:

Tabel 4. Statistik Data Tes Awal dan Tes Akhir.

Paired Samples Statistics

\begin{tabular}{lllllr}
\hline & Mean & $\mathrm{N}$ & $\begin{array}{c}\text { Std. } \\
\text { Deviation }\end{array}$ & $\begin{array}{c}\text { Std. } \\
\text { Error } \\
\text { Mean }\end{array}$ \\
\hline Pair & Pretest & 45.33 & 12 & 2.871 & .829 \\
\cline { 2 - 6 } 1 & Posttest & 48.00 & 12 & 3.275 & .945 \\
\hline
\end{tabular}

Berdasarkan data pada tabel 3 dapat diketahui nilai rata-rata (mean) pada tes awal sebesar 45,33 dan pada tes akhir sebesar 48 . Hal ini menunjukkan adanya peningkatan atas penerapan perlakuan. Untuk mengetahui ada tidaknya perbedaan, dapat diketahui pada uji Paired Sample Test sebagai berikut: 
Tabel 5. Hasil Uji Paired Sample Test.

\begin{tabular}{|c|c|c|c|c|c|c|c|c|c|}
\hline \multicolumn{10}{|c|}{ Paired Samples Test } \\
\hline & & \multicolumn{5}{|c|}{ Paired Differences } & \multirow[b]{7}{*}{$\mathrm{t}$} & \multirow[b]{7}{*}{$\begin{array}{l}d \\
f\end{array}$} & \multirow{7}{*}{$\begin{array}{l}\text { Sig. } \\
(2- \\
\text { taile } \\
\text { d) }\end{array}$} \\
\hline & & \multirow[b]{6}{*}{$\begin{array}{c}\text { Mea } \\
\mathrm{n}\end{array}$} & \multirow{6}{*}{$\begin{array}{c}\text { Std. } \\
\text { Deviatio } \\
n\end{array}$} & \multirow{6}{*}{$\begin{array}{l}\text { Std. } \\
\text { Erro } \\
r \\
\text { Mea } \\
n\end{array}$} & \multirow{5}{*}{\multicolumn{2}{|c|}{$\begin{array}{c}95 \% \\
\text { Confidence } \\
\text { Interval of } \\
\text { the } \\
\text { Difference } \\
\end{array}$}} & & & \\
\hline & & & & & & & & & \\
\hline & & & & & & & & & \\
\hline & & & & & & & & & \\
\hline & & & & & & & & & \\
\hline & & & & & $\begin{array}{c}\text { Low } \\
\text { er }\end{array}$ & $\begin{array}{l}\text { Upp } \\
\text { er }\end{array}$ & & & \\
\hline \multirow{3}{*}{$\begin{array}{l}\text { Pai } \\
\text { r } 1\end{array}$} & Pretes & & & & & & & & \\
\hline & $\mathrm{t}-$ & 2.66 & 1.231 & .355 & 3.44 & $1.88^{-}$ & $7.50^{-}$ & 1 & .000 \\
\hline & $\begin{array}{l}\text { Postte } \\
\text { st }\end{array}$ & $\begin{array}{r}2.00 \\
7\end{array}$ & 1.201 & כבנ. & $\begin{array}{r}.44 \\
9\end{array}$ & 5 & 5 & 1 & \\
\hline
\end{tabular}

Berdasarkan hasil uji Paired Sample Test diperoleh nilai Sig. (2-tailed) $=0,000$. Karena nilai Sig. $=0,000<0,05$ maka disimpulkan ada perbedaan antara sebelum dan sesudah perlakuan. Nilai $t_{\text {hitung }}=-7,505$, nilai $t_{\text {tabel }}$ dengan $\mathrm{N}=12(\mathrm{df}=\mathrm{n}-1=12-1=11)$ pada taraf signifikansi $5 \%$ ditemukan nilai $t_{\text {tabel }}=2,62$. Karena nilai $t_{\text {hitung }}>$

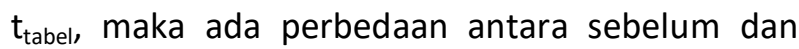
sesudah perlakuan. Berdasarkan data statistik yang ditunjukkan pada tabel 3 dapat diketahui besarnya peningkatan antara sebelum dan sesudah diberi perlakuan dan sesudah sebesar 2,77 . Lebih jelas dapat dilihat pada grafik berikut:

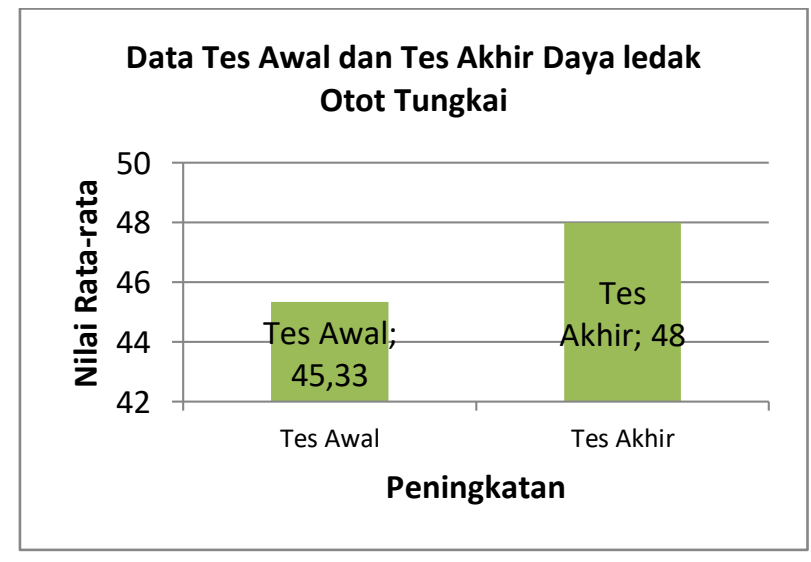

Grafik 1. Hasil Pengukuran Daya Ledak otot Tungkai.

\section{PEMBAHASAN}

Penelitian ini bertujuan untuk mengetahui pengaruh metode bermain terhadap daya ledak otot tungkai atlet bolavoli Pervik Kediri. 12 atlet yang menjadi subyek dalam penelitian ini menjalani program latihan dengan perlakuan metode bermain tiga kali seminggu tiap hari
Selasa, Kamis dan Sabtu, selama lima minggu. Hasil analisis data menunjukkan adanya perbedaan antara sebeum dan sesudah perlakuan, hal ini berarti metode bermain berpengaruh secara signifikan terhadap peningkatan power otot tungkai.

Latihan dengan metode bermain, secara signifikans bisa meningkatkan power atlet bolavoli Pervik Kediri, yang dipersiapkan sebagai tim yang ikut seleksi. Latihan meningkatkan fisik, khususnya power otot tungkai, dilakukan dengan melompat memakai bola atau tanpa bola pada situasi bermain, gembira, membuat atlet tidak merasa berlatih dengan tertekan, dan senang dalam melakukannya, sehingga tanpa terasa mereka melompat berkali-kali tanpa terasa. Hal ini sesuai apa yang dijelaskan oleh Hidayat, Riyanto, \& Rosman (2018) bahwa permainan memungkinkan anak mempraktekkan kompetensi-kompetensi dan keterampilan-keterampilan yang diperlukan dengan cara yang santai dan menyenangkan.

Keunikan dari kegiatan bermain terletak pada proses yaitu pemain memberikan keputusan untuk melakukan dan menerapkan suatu teknik secara tepat dalam situasi yang berubah-ubah. Oleh sebab itu, keputusan yang diambil secara tepat dalam situasi bermain merupakan faktor yang penting.

Power otot tungkai merupakan kemampuan sekelompok otot tungkai untuk melakukan gerak secara eksplosif ketika melakukan lompatan (Candra, 2016). Power merupakan kemampuan otot mengerahkan kekuatan maksimal dalam waktu yang sangat cepat untuk mengatasi beban atau tahanan dengan kecepatan kontraksi yang tinggi (Pembayun, Wiriawan, \& Setijono, 2018). Power otot tungkai merupakan komponen kondisi yang sangat penting dalam permainan bolavoli. Smash dan block merupakan teknik dasar dalam permainan bolvoli yang memerlukan power otot tungkai. Power otot tungkai menunjang lompatan pemain bolavoli dalam melakukan smash dan 
block. Tanpa lompatan yang tinggi, pemain akan kesulitan melakukan smash dan block.

Hasil temuan terdahulu menyebutkan bahwa metode bermain dapat meningkatkan keterampilan teknik dasar bermain bolavoli (Sanur, 2017; Rithaudin \& Hartati, 2016; Indriyani, 2011; Astuti, 2017). Hasil temuan penelitian ini diharapkan dapat berkontribusi bagi ilmu pengetahuan khususnya dalam meningkatkan power otot tungkai menggunakan metode bermain. Metode ini memang perlu dikembangkan lebih lanjut, dengan bisa menambah pola dan variasi, sehingga bisa didapatkan hasil yang lebih baik dan ilmiah.

\section{SIMPULAN DAN REKOMENDASI}

Power otot tungkai dapat meningkat secara signifikan dengan penerapan metode bermain. Hasil penelitian ini diharapkan dapat dikembangkan lebih lanjut untuk mendapatkan temuan yang lebih baik khususnya dalam menerapkan metode bermain dalam meningkatkan power otot tungkai.

\section{REFERENSI}

Astuti, Y. (2017). Pengaruh Metode Drill dan Metode Bermain Terhadap Keterampilan Bermain Bola Voli Mini (Studi Eksperimen Pada Siswa SD Negeri 14 Kampung Jambak Kecamatan Koto Tangah Kota Padang). Al Ibtida: Jurnal Pendidikan Guru MI, 4(1), 116.

https://doi.org/10.24235/al.ibtida.snj.v4i1 .1276

Candra, A. (2016). Studi Tentang Kemampuan Lompat Tegak Siswa Sekolah Dasar Negeri Berdasarkan Perbedaan Geografis Sebagai Identifikasi Bakat Olahraga. Jurnal SPORTIF : Jurnal Penelitian Pembelajaran, 2(2), 1$14 . \quad$ Retrieved from http://ojs.unpkediri.ac.id/index.php/pik/a rticle/view/511.

Hanief, Y. N., Puspodari, P., \& Sugito, S. (2017). Profile of physical condition of Taekwondo Junior Athletes Pusklatkot (Training centre) Kediri city year 2016 to compete in
2017 east java regional Competition. International Journal of Physiology, Nutrition and Physical Education, 2(2), 262-265. Retrieved from http://www.journalofsports.com/archives /2017/vol2/issue2/PartE/2-2-19

Hidayat, S., Riyanto, P., \& Rosman, D. B. (2018). Pengaruh Metode Bermain Terhadap Peningkatan Passing Bawah dalam Permainan Bola Voli Siswa Eksrakurikuler SMK Negeri 1 Subang. BIORMATIKA: Jurnal IImiah Fakultas Keguruan Dan IImu Pendidikan, 4(1).

Indriyani, D. (2011). Peningkatan Hasil Belajar Passing Bawah Pada Bola Voli dengan Menggunakan Permainan " 3 On 3 " Pada Siswa Kelas VII SMP Negeri 1 Sukoharjo Wonosobo Tahun Pelajaran 2010 / 2011. Universitas Negeri Semarang.

Maliki, O., Hadi, H., \& Royana, I. F. (2017). Analisis Kondisi Fisik Pemain Sepak Bola Klub PERSEPU UPGRIS Tahun 2016. Jendela Olahraga, 2(2), 1-8.

Muchlisa, A. W. (2017). Pengaruh Koordinasi Mata-Tangan, Daya Ledak Otot Tungkai dan Motivasi Berprestasi Terhadap Keterampilan Smash. Jurnal Pendidikan Jasmani, 30(2), 1-7.

Muttaqin, I., Winarno, M. E., \& Kurniawan, A. (2016). Pengembangan Model Latihan Smash Bolavoli Pada Kegiatan Ekstrakurikuler di SMPN 12 Malang. Pendidikan Jasmani, 26(2), 257-272.

Pembayun, D. L., Wiriawan, O., \& Setijono, $H$. (2018). Pengaruh Latihan Jump To Box, Depth Jump dan Single Leg Depth Jump Terhadap Peningkatan Kekuatan Otot Tungkai dan Power Otot Tungkai. Jurnal SPORTIF : Jurnal Penelitian Pembelajaran, 4(1), https://doi.org/10.29407/js_unpgri.v4i1.1 2006

Prakoso, G. P. W., \& Sugiyanto, F. (2017). Pengaruh Metode Latihan dan Daya Tahan Otot Tungkai terhadap Hasil Peningkatan Kapasitas Vo2max Pemain Bola Basket. Jurnal Keolahragaan, 5(2), 151-160. Retrieved from https://journal.uny.ac.id/index.php/jolahr aga/article/view/10177/9869 
Pratiwi, F. Z., Setijono, H., \& Fuad, Y. (2018). Effect of Plyometric Front Cone Hops Training and Counter Movement Jump Training to Power and Strenght of Leg Muscles. Jurnal SPORTIF : Jurnal Penelitian Pembelajaran, 4(1), 105-119. https://doi.org/10.29407/js_unpgri.v4i1.1 2073

Purnama, G. S. (2015). Tinjauan Kondisi Fisik Pemain Sekolah Sepakbola (SSB) Generasi Muda Ganting (GMG) Kelompok Umur-15 Kota Padang Panjang. Jurnal Pendidikan Jasmani Kesehatan Dan Rekreasi, 1(1), 111.

Rithaudin, A., \& Hartati, B. S. (2016). Upaya Meningkatkan Pembelajaran Passing Bawah Permainan Bola Voli dengan Permainan Glagahombo I Tempel Sleman Yogyakarta. Jurnal Pendidikan Jasmani Indonesia, 12(1), 51-57.

Rizaldianto, D. (2016). Kondisi Kapasitas Fisik (Kekuatan, Daya Tahan, Kecepatan, dan Daya Ledak) dan Kadar Hemoglobin Atlet Balap Sepeda Jalan Raya ISSI Kota Semarang Tahun 2016. Universitas Negeri Semarang.

Sanur, S. (2017). Upaya Meningkatkan Hasil Belajar Servis Atas Permainan Bola Voli Dengan Pendekatan Bermain Pada Siswa Kelas VI SDN Batokerbuy 2 Tahun Ajaran 2015/2016. Jurnal SPORTIF : Jurnal Penelitian Pembelajaran, 2(1), 93-100. https://doi.org/10.29407/js_unpgri.v2i1.6 60

Wijaya, B. S. (2013). Pengaruh Metode Bermain Terhadap Peningkatan Passing Bawah Bolavoli Peserta Ekstrakurikuler di SMA Negeri 1 Bantul. Universitas Negeri Yogyakarta.

Yudasmara, D. (2014). Pengembangan Model Latihan Teknik Block dalam Bolavoli. Jurnal IPTEK, 16(1), 79-102. 